where $q$ is the number of quasi-free electrons per atom and $V_{0}$ is the value of the maximum electron energy at absolute zero expressed in equivalent volts. Thermal expansion decreases $V_{0}$ and hence increases $\left(\psi_{A}\right)_{e}$. Cold-work, on the other hand, should also decrease $V_{0}$, since it may be considered as giving rise to a trapping of electrons in regions of lower potential energy. To account for the smaller decrease of sus. ceptibility with temperature in the case of the coldworked specimens, it is then necessary to suppose that further decrease in $V_{0}$ is less than for the annealed metal.

Further work will be published elsewhere.

$$
\text { T. S. HuTChrson }
$$

J. REEKIF

Department of Physics,

University, St. Andrews. Feb. 10.

1 Hutchison, T. S., and Reekie, J., J. Sci. Instr., 23, 209 (1946).

${ }^{8}$ Reekie, J., and Hutchison, T. S., Nature, 157, 807 (1946).

${ }^{3}$ Bitter, F., Phys. Rev. 36, 978 (1930).

'Lowance, F. E., and Constant F. W., Phys. Rev., 38, 1547 (1931).

'Kussman, A., and Seemann, H. J., Naturwiss., 19. 309 (1931). Z. Phy8., 77, 567 (1932).

- Stoner, E. C., Proc. Roy. Soc., A, 152, 672 (1935).

'Sucksmith, W., Phil. Mag., 2, 21 (1926).

\section{'Incipient Shrinkage' of Collagen and Gelatin}

IT is well known that if collagen is heated in water to about $62^{\circ} \mathrm{C}$. it undergoes shrinkage, and that if it is then allowed to dry, its ability to re-hydrate on immersion in water is considerably reduced. Although opinions differ as to the precise mechanism of hydrothermal shrinkage, the phenomenon is generally agreed to be a cumulative effect in which the poly. peptide chains, by the rupture of certain cross-links of various strengths, assume a more compact space arrangement than their hitherto extended forms. On drying in this compact state, their ability to take up water is considerably reduced, due probably to the formation of fresh inter-chain links.

A similar reduction in the re-hydrating power of collagen, but not accompanied by shrinkage, can be obtained by heating it in an atmosphere of high relative humidity at temperatures so low as $45^{\circ} \mathrm{C}$. Deaminated collagen and gelatin also show this effect, and in the case of gelatin, it is accompanied by an elevation in 'melting point', which may amount to as much as $50^{\circ} \mathrm{C}$. or more, where thin gelatin layers are concerned. Under conditions of very high relative humidity (c. 100 per cent) gelatin undergoes marked hydrothermal shrinkage at $45^{\circ} \mathrm{C}$., and exhibits rubber-like properties similar to shrunken collagen, a phenomenon not usually observed with gelatin on account of its ready solubility in water at about $35^{\circ} \mathrm{C}$.

The accompanying table shows the magnitude of the changes in absorption of water of the three proteins referred to, brought about by heating in atmospheres of various relative humidities at $45^{\circ} \mathrm{C}$. In each ease, after heating at $45^{\circ} \mathrm{C}$., the protein was allowed to come to equilibrium with an atmosphere of 70 per cent relative humidity at $20^{\circ} \mathrm{C}$., and in no case did the final weight differ from the original, before heating, by more than 1 per cent. The water absorption figures indicate the grams of water absorbed by $100 \mathrm{gm}$. of protein when immersed in distilled water at $20^{\circ} \mathrm{C}$. for three days in the case of the collagens, and 36 hours in the case of gelatin.

\begin{tabular}{|c|c|c|c|c|c|}
\hline Protein & $\begin{array}{l}\text { Period of heat- } \\
\text { ing at } 45^{\circ} \mathrm{C} . \\
\text { (days) }\end{array}$ & \multicolumn{4}{|c|}{ 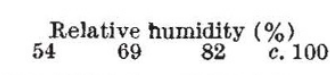 } \\
\hline Collagen & $\begin{array}{r}5 \\
20 \\
80\end{array}$ & $\begin{array}{r}126 \\
104 \\
97\end{array}$ & $\begin{array}{r}124 \\
103 \\
94\end{array}$ & $\begin{array}{r}113 \\
93 \\
90\end{array}$ & $\begin{array}{r}111 \\
88 \\
75\end{array}$ \\
\hline \multicolumn{2}{|c|}{ Untreated collagen, 126} & \multicolumn{4}{|c|}{ shrunken* collagen, 95} \\
\hline Deaminated & 5 & 100 & 102 & 100 & 92 \\
\hline Collagen & 20 & 86 & 89 & 89 & 76 \\
\hline Gelatin & $\begin{array}{r}80 \\
5\end{array}$ & $\begin{array}{r}85 \\
645\end{array}$ & $\begin{array}{r}84 \\
643\end{array}$ & $\begin{array}{r}74 \\
567\end{array}$ & $\begin{array}{c}58 \\
435 \dagger\end{array}$ \\
\hline
\end{tabular}

* Collagen shrunken by immersion in distilled water at $90^{\circ} \mathrm{C}$. for 3 min., allowed to dry out at $20^{\circ} \mathrm{C}$. Some gelatinization had occurred, and therefore the water uptake figure given is probably higher than the real value for shrunken collagen.

$\uparrow$ Hydrothermal shrinkage observed.

Air-dried collagen, containing about 13 per cent of water, can be heated in air to at least $100^{\circ} \mathrm{C}$. without showing signs of shrinkage. Only when heated at this temperature in an atmosphere of practically 100 per cent relative humidity, or in the presence of excess water, does shrinkage occur. Since heating a protein in an atmosphere of high relative humidity is merely equivalent to heating it under conditions of comparatively high water content, it is apparent that a certain minimum water content is necessary before shrinkage can take place, even at temperatures so high as $100^{\circ} \mathrm{C}$.

It seems likely that the effect which has been described is due to the rupture of some of the weaker cross-bonds of the protein molecule, which permits local increases in compactness, followed, on drying, by the formation of new cross-bonds. Physical shrinkage is not observed since insufficient links are so affected.

On this hypothesis, the term 'incipient shrinkage' seems appropriate to describe the phenomenon.

\section{British Leather Manufacturers' Kenneth Pankhurst \\ Research Association, \\ 1-6 Nelson Square, \\ London, S.E.1. \\ Feb. 19. \\ Exchange between Chromium lons and the Szilard Effect}

Chromium hydroxide $\left(\mathrm{Cr}(\mathrm{OH})_{3}\right.$ ) was subjected to the action of slow neutrons produced by the cyclotron of the College de France and was then transformed into the sulphate by dilute sulphuric acid. Potassium dichromate was added to this solution of the sulphate so as to obtain an equimolecular system of $\mathrm{Cr}^{+++}$ and $\frac{1}{2} \mathrm{Cr}_{2} \mathrm{O}_{7}--$. After a time which varied from 15 to 120 minutes, the chromic salt was precipitated by boiling with ammonium hydroxide and the dichromate as the barium salt.

The activities of these precipitates, as measured by a Geiger-Müller counter, showed that in the neutral or acid medium there was no appreciable exchange. The following, for example, are the results obtained for a solution of $p \mathrm{H}$ about 3 .

$\begin{array}{crr}\text { Time of contact } & \mathrm{Cr}(\mathrm{OH})_{3} & \mathrm{BaCrO}_{4} \\ 15 \text { min. } & 116 \pm 10 & 10 \pm 7 \\ 60, " & 83 \pm 11 & 0 \pm 6 \\ 120, & 71 \pm 10 & 7 \pm 6\end{array}$

Potassium iodide, which catalyses the exchange between arsenite and arsenate, has no action in our case.

The impossibility of observing an exchange between the $\mathrm{Cr}+++, \mathrm{Cr}_{2} \mathrm{O}_{7}--$ ions leads one to think that it would be easy to find a Szilard and Chalmers 